\title{
Analysis of the Spatial and Temporal Dynamics of Street Hawking: A Case Study of the Accra Metropolitan Area
}

\author{
Alex Barimah Owusu ${ }^{1}$, Stephen Abrokwah ${ }^{1} \&$ Stephen Frimpong ${ }^{2}$ \\ ${ }^{1}$ Department of Geography and Resource Development, University of Ghana, Accra, Ghana \\ ${ }^{2}$ Institute for Natural Resources in Africa, United Nations University, Accra, Ghana \\ Correspondence: Alex Barimah Owusu, Department of Geography and Resource Development, University of \\ Ghana, Accra, Ghana. Tel: 233-200-848-906. E-mail: owusuba@yahoo.com
}

\author{
Received: September 3, 2013 Accepted: November 12, 2013 Online Published: November 28, 2013 \\ doi:10.5539/jgg.v5n4p169 \\ URL: http://dx.doi.org/10.5539/jgg.v5n4p169
}

\begin{abstract}
To the street hawker, it is a means of making a living but to the managers of the metropolis, street hawking is a menace. These differences in perception have led to a game plan tied to spatio-temporal diurnal traffic regimes. While the city authorities plan may be to evict the street hawkers, the plan of the hawkers is to outwit the city authorities through make-shift hawking patterns in order to make a living. The difference in the two positions can be characterized by the city manager's need for clean and less congested city streets, and the hawker's desire to sell wares at locations that maximize income. The factors contributing to street hawking include traffic congestion, profitability, the lack of employable skills and minimal-capital entry requirement into the hawking trade. While the city needs proper spatial planning in the long run, in the short term, city managers and hawkers must develop a relationship that considers public perceptions and the use of public space to make the Accra metropolitan area livable. This calls for new approaches that address the aesthetic and open space needs while at the same time meeting the socio-economic and survival needs of city dwellers and new immigrants.
\end{abstract}

Keywords: spatio-temporal, rural-urban drift, street hawking, geospatial analysis

\section{Introduction}

Economic disparities existing between countries have the tendency of creating population drift. The more economically developed countries tend to pull people from relatively less developed countries in search of economic opportunities (Dickson \& Benneh, 1988). For instance, a conservative estimate shows that the number of economic migrants from Mexico who moved to the United States of America (USA) in search of economic opportunities were about 12 million people in 2007. However, the number dropped to 11.6 million in 2008 and subsequently to 11.5 million in 2009 due to economic recession that affected the USA economy (Jordan, 2009). Similarly, national economic disparities in countries have been a key factor to rural-urban migration and perhaps the existence of primate cities globally and Africa in particular.

The concept of primacy relates to urban hierarchy in which the leading city in a country or region becomes disproportionately larger than any surrounding region. The proponents of primacy argued that the phenomenon occurs when the largest city is at least twice the size of the next largest city as well as more than twice the population density of the second. Some examples of primary cities in Africa include Lagos (Nigeria), Cairo (Egypt), Kinshasa (Congo DR), and Accra (Ghana). The regional economic disparities between towns (cities) in Africa have made these primary cities centers for economic opportunities and personal fulfillment. Hence any countryside dweller who seeks to better his or her life immediately thinks of moving to the city. Taking Ghana for example, Accra is the dominant city with its population almost twice that of Kumasi, the second largest city. Accra hosts all government ministries and departments, has the only international airport in Ghana, boasts of almost all business head offices where hiring and firing takes place, contains all foreign embassies and above all the headquarters of financial institutions. This has created a situation where citizens requiring jobs would have to travel to Accra. Similarly retiring civil servants seeking end of service benefits would also have to make a number of trips to Accra no matter where one lives in Ghana. A direct result of the concentration of opportunities in Accra is a constant influx of immigrants from the countryside seeking economic opportunities. These economic migrants move to Accra in hopes of good jobs, better pay, good housing and a more exciting lifestyle. However, frustration begins at the city entrance where they are greeted with traffic congestion. The situation 
worsens when these economic migrants realize that the big towns and cities do not have jobs ready and waiting for them. This situation leads migrants and indeed some indigenes into creating other forms of livelihood to earn a living which includes selling merchandise on the street, often termed street hawking.

The primacy of cities is not bad in itself as it contributes substantially to Gross Domestic Product serves as cradles of innovation and may have trickledown effect on subjacent communities. However, the rate at which urbanization is occurring in Ghana with its attendant problems of a burgeoning urban population and excessive traffic congestion has become a drain on national resources. As such it is worthy of greater study. Like most cities in a developing country, Accra has a long standing history of street hawking. However the recent boom of street hawkers can be partly attributed to the Structural Adjustment Programme (SAP) implemented in Ghana in the early 1980s. The programme involved trade liberalization, public sector reform, downsizing government expenditure and educational reforms, all of which led to mass public sector retrenchment, increased school dropout and mass importation of cheap manufactured products. The recent global economic meltdown in 2008 has also increased economic hardships on households in many countries as evident by the high unemployment rates in Ghana (Hart, 1973). Street trading has intensified over the last couple of decades as it became the easiest avenue for people affected by SAP, global economic meltdown and trade liberalization. In fact, trade liberalization has made available the various kinds of cheap products that are sold on the streets of Accra. Also, increase in the number of motor vehicles has overwhelmed road capacity and has, therefore, exacerbated traffic congestion. Most of the significantly congested intersections serve as gathering points for street hawkers. In the face of limited economic opportunities, people tend to employ street hawking as a means of making a living (Sarfo, 1997). Thus, unemployment, the availability of cheap products and services and the urban traffic congestion all aid the proliferation of street hawking. However, since street hawkers typically ignore local regulations and by-laws, the areas where they operate tend to be, generally disorganized (Gyamfi, 2000). Their non-regulation culminates in, unsafe and unhygienic conditions that city authorities deem as nuisance and unprofitable uses of the urban space (Jimu, 2005).

Even though street hawking has been featured in the news media for some time now, research from academic circles is less well represented (Bromley, 1998). Hays-Mitchell (1994) and Jimu (2005) noted that most investigations into this subject area have been in studies of informal manufacturing (Asiedu \& Agyei-Mensah, 2008). This creates a gap in knowledge regarding the spatial dimension and modification of the urban landscapes by street hawking. Asiedu and Agyei-Mensah (2008) analyzed street hawker demographics and argued that due to the gender bias in educational system of developing countries, women normally dominate this line of economic activity. They further reported that men join the street trade at younger ages but later leave after finding higher-paid, formal jobs whereas women tend to be stuck in the street trade until old age. A study by Gyamfi (2000) confirms that the number of street traders inAccra have risen since late 1990s as a result of the high rates of unemployment in the city. Gyamfi further states that youth prefer selling on the street to selling in the market centers in order to avoid open clashes with store owners. It is imperative to describe these hawkers: where they come from, the spatial dimension of their operation and how they deal with eviction, and the problems they pose to the urban environment. Iyenda (2005) points out that irregularities in their hawking times as well as the mobile nature of their activities makes extracting this data quite a challenge. In this light the objective of this study is to provide urban planners and policymakers an insight into street hawking and its areas of concentration. They could be used for developing remedial action to disperse street hawkers or for monitoring their activities. It could also serve as early warning systems for possible invasion of street hawkers when new traffic patterns develop.

\subsection{Extent of Street Hawking in Ghana}

In Ghana, street hawking is of serious concern due to increasing numbers of people selling and the resultant friction that ensues between street hawkers and city authorities (Iyenda, 2005; Gyamfi, 2000). The swelling numbers of street hawkers is attributed to the massive rural-urban migration, lack of formal sector required skills and the non-existence of job vacancies in the formal sector to absorb the influx (Dickson \& Benneh, 1988).

A cursory look at urbanization rates, economic development trends, the extent of street congestion and the increasing visibility of street hawkers suggest that there could be large increases in the number of street traders operating on the streets of African cities in the next couple of years. In an effort to address the paucity of street hawking data as a precursor to reducing the street hawking, the following questions are considered:

- What is the origin of street hawkers in Accra Metropolitan area?

- Why is street hawking endemic in the city of Accra?

- Is street hawking likely to end? 
The city's inability to address the phenomenon has generated public outcry and criticism attributable to lack of understanding by the civil authority of the magnitude or how widespread is street hawking. This study provides baseline information in terms of spatial patterns and demography of hawkers to inform policy.

\subsection{Urbanization and Street Hawking Nexus in Africa}

According to the International Labor Organization (2002), urbanization in Africa is a relatively recent phenomenon except for West Africa and some coastal east African towns. Figure 1 presents sub-regional urbanization levels in 1995 and 2007, as well as urban growth rates from 2005-2010. Figure 1 shows southern Africa is the most urbanized although it grew marginally in 2005-2010. Central or middle Africa which is the third most urbanized region had the highest growth rate between 2005 and 2010 while west and east Africa grew at a rate of $3.7 \%$.

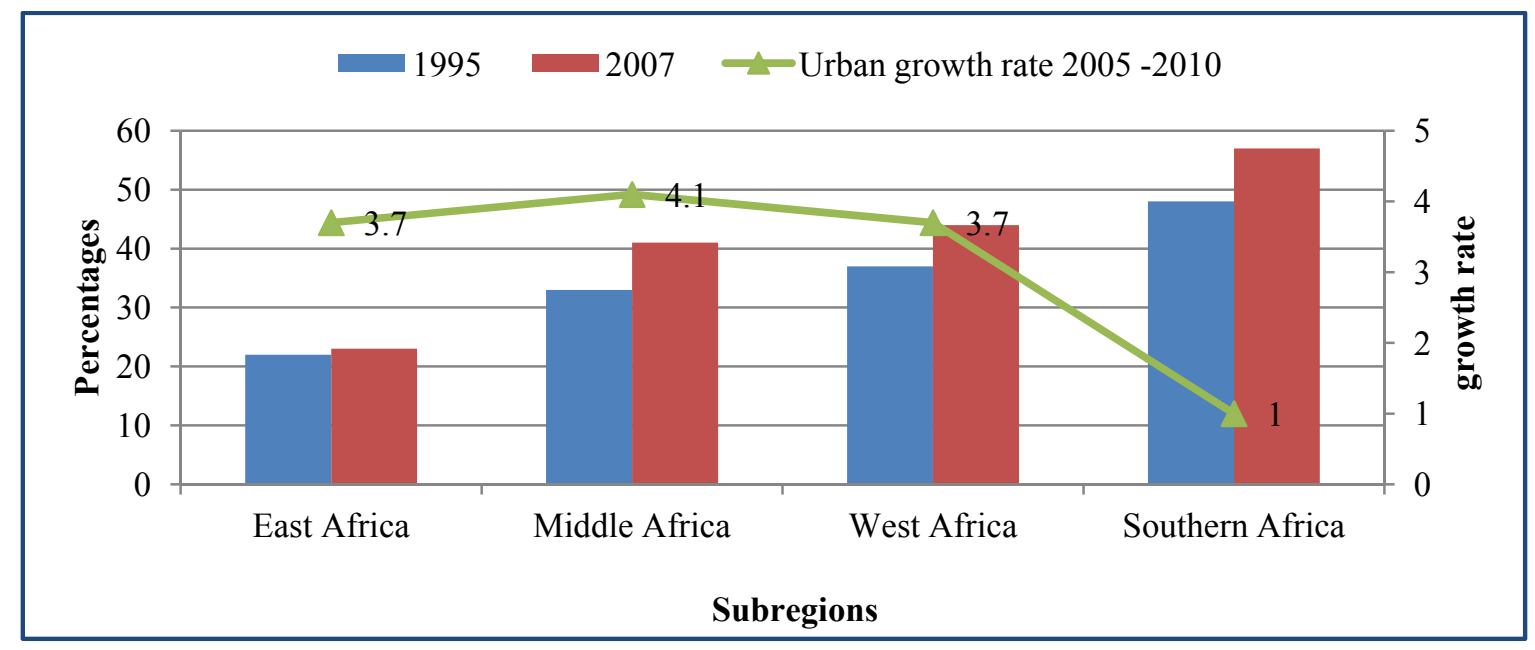

Figure 1. Percentage of total population in urban areas and urbanization rates for the four sub-regions of Sub-Sahara Africa

Source: ILO (2002).

Of particular interest is the urbanization process that leads to the swelling numbers of street hawkers in developing countries, particularly in Africa. As Landau (2007) points out, migration is an inexorable response to regional economic inequalities. Migrants to urban centers move with the intention to work, however upon reaching an urban center, they find formal job opportunities are limited. They therefore turn to other alternatives such as street trading. This mode of urbanization is problematic for urban managers in such countries. It is generally observed that street hawkers often work outside the law, especially those associated with tax liabilities, labour codes and zoning regulations (Jimu, 2005). As a result, there exists an essential conflict between hawkers and city managers in their aim to ensure adherence to city management regulations. Lund et al. (2000) makes the case that despite the services provided by street hawkers to the general public, their efforts are not viewed as lawful and beneficial by authorities. Vishwanath (2001) in his examination of the activities of street hawkers in Bangkok reported that raids and evictions are the usual tools of the city managers in dealing with street traders.

Mitullah (2003) suggests that the availability of an acceptable site of operation is a pre-condition for compliance with various statues relating to business operations. Most street vendors in Africa have no authorized sites of operation, which leads to the inevitable confrontation between street vendors and city authorities. The authorities are often reluctant to allocate hawking sites, especially within the Central Business District (CBD). In the cases of Nairobi and Kampala, a study found that hawkers had been allocated vending sites outside the CBD which they rejected based on the argument that those locations were not accessible to customers. Vishwanath (2001) and Cross (1997) argue that the basis of hawker harassment is the approximation of modernization with westernization by city authorities which creates the impression that the presence of large street market was the clearest sign of disorderly nature of the informal economy that needed to be curbed. Bromley's (1998) also confirmed Cross' (1997) findings. Bromley (1998) further argued that there appears to be a widely held perception that street trading is a manifestation of both poverty and underdevelopment and its disappearance is viewed as progress. As such, aggressive policing is often pursued by city managers to dislodge street hawkers, 
particularly just before major public and tourist events, on the assumption that orderly streets improve the image of the city to visitors.

Agbo (2010) observed that in Abuja, Nigeria, street traders have always been victims of persistent raids carried out by city authorities. The reason has always been the desire to make Abuja an exceptionally neat capital city compared to modern cities anywhere in the world. In South Africa, Nesvag (2000) noted that street traders were particularly harassed by the apartheid regime as part of the strategy of preventing Africans from taking control of public space. Similarly, Rogerson and Hart (1989) argued that South African urban authorities fashioned and refined a set of anti-street trader measures that allow for the continued repression, and prosecution of street traders until the early 1980s. In Tanzania, Nnkya (2006) documents the harassment of street traders by the government in the mid-1970s. She noted that traders operating in the capital city were forcibly evicted to villages on the coast; under the guise that street trading activities undermines socialist principles.

City authorities and policy makers usually do not have data regarding the profile, mode of operations and contributions of street hawkers to national economies in depth; hence, their business receive little or no support (Gyamfi, 2000). Also, knowledge of their mode of operations, personal data as well as volume of sales is relevant for efficient planning and appreciation of the contribution of street trade to national economy. However, this information is generally lacking since most traders lack written records of income and expenditure.

\section{Methodology}

Both qualitative and quantitative methods are employed to obtain data on the nature and provenance of street hawkers. The approach included in-depth interviews of key informants as well as focus group discussions. The quantitative method involved data collection on geospatial data and attributes data from respondents using global positioning system and structured questionnaires respectively. Multi-stage sampling approach was used in selecting respondents. This involved purposive sampling of nine (9) out of the eighteen main hawking locations of Accra Metropolitan Area and systematic random sampling of respondents or street hawkers. The nine locations selected are shown in Figure 2 and include the Graphic Road traffic light, the New Achimota Station Traffic Light, 37 Roundabout Traffic Light, Mallam Junction, Airport Junction Traffic Light, Osu Food Court, Busy Internet of the Nkrumah Circle, Nima Junction and Lapaz Traffic Light.

The purpose of the study was clearly explained to respondents and participation in the study was voluntary. Respondents were also given opportunity to drop out any time in the course of the interview. In all 180 respondents were sampled for the study. All the study sites were located within the boundaries of Accra Metropolitan Area (AMA). The metropolis has eleven sub- metropolitan areas and occupies a total land surface area of approximately $173 \mathrm{~km}^{2}$. It is bordered to the north by Adenta, Ga East and Ga West Districts, to the east by Tema Metropolitan Area, to the west by Ga South District and the south by the Gulf of Guinea (Figure 3). It has a total population of 1,848,614 with 960,941 being females and 887,678 being males (GSS, 2012). AMA is a major industrial center of the Greater Accra Region.

\section{Results and Discussions}

\subsection{Geospatial and Temporal Pattern of Street Hawking in AMA}

Regarded as the most significant aspect and a core component of the informal economy in Africa (Nnkya, 2006), street hawking accounts for $60 \%$ of all urban jobs on the continent and has become a permanent feature of most urban and semi-urban centers in Africa (Skinner, 2010; Suarez, 2013.), including Ghana. In Ghana this observation is especially true in the city centers of Accra and Kumasi (Sarfo, 1997). Within the Accra Metropolis hawkers are literally found on all major roads and, as a matter of strategy, concentrated around traffic lights, with the hope of accessing the occupants when a vehicle stops in response to the traffic light signal. However, a thorough observation of the various hawking location across the metropolis reveal 18 main hawking points. These are shown in Figure 2 explained by the weight of commercial activities; density of passersby as well as vehicular traffic, these areas provide the attraction and the promise of a profitable hawking business. 


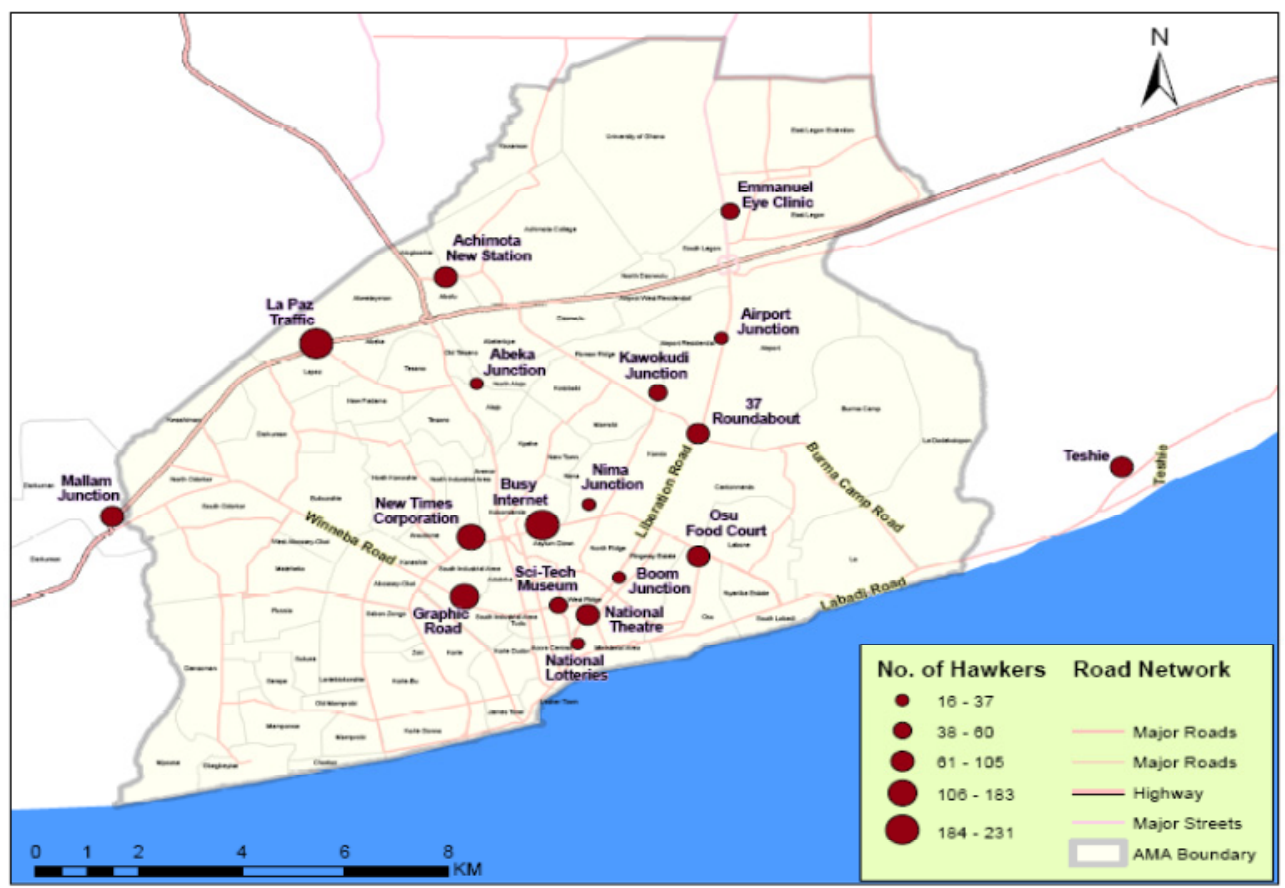

Figure 2. Major hawking locations and the estimated number of hawkers as of March 31st, 2011

\subsection{Distribution of Hawkers Based on Migrants Region and Destination of Hawking}

The study also considered the location of hawkers to map the principal provinces and number of individuals from all over Ghana who immigrate to Accra and engage in the street trade. Figure 3, shows the percentage of hawkers in Accra from the surrounding regions. Figure 3 shows that people from three regions (Ashanti, Central and Eastern) dominate hawking activities. The remaining seven regions recorded marginal migration which is consistent with Asiedu and Agyei-Mensah (2008). The Ashanti Region contributes the largest number of individuals with $30 \%$ of the total 180 sampled population. This is not surprising as Ashantis are described as entrepreneurs and tend to prefer to be self-employed rather than seeking paid employment or work for others. Central Region which is understood to be one of the underdeveloped regions in Ghana followed with $23.3 \%$. The Eastern Region came third with hawking population of $20 \%$ of the sampled population. Based on the numbers from Central and Eastern regions, it is may be reasonable to posit that people migrate to Accra as a means to escaping the poverty in hope of a better circumstance to earn a living and remit back home to help the family (Asiedu \& Agyei-Mensah, 2008), though the same cannot be said of the Ashanti Region. The large number of migrants from Eastern and Central regions may also be postulated to have been caused by their proximity and the general absence of major intervening cities as compared to the Northern, Upper East and Upper West Regions which have Kumasi and Techiman as intervening cities. The Greater Accra Region, Western, Volta and the Brong Ahafo Regions recorded 6.7\%, 4.4\%, 3.9\%, and 3.9\% respectively whereas the Upper West, Upper East and Northern Regions recorded 3.3\%, 2.9\% and 1.7\% respectively. 


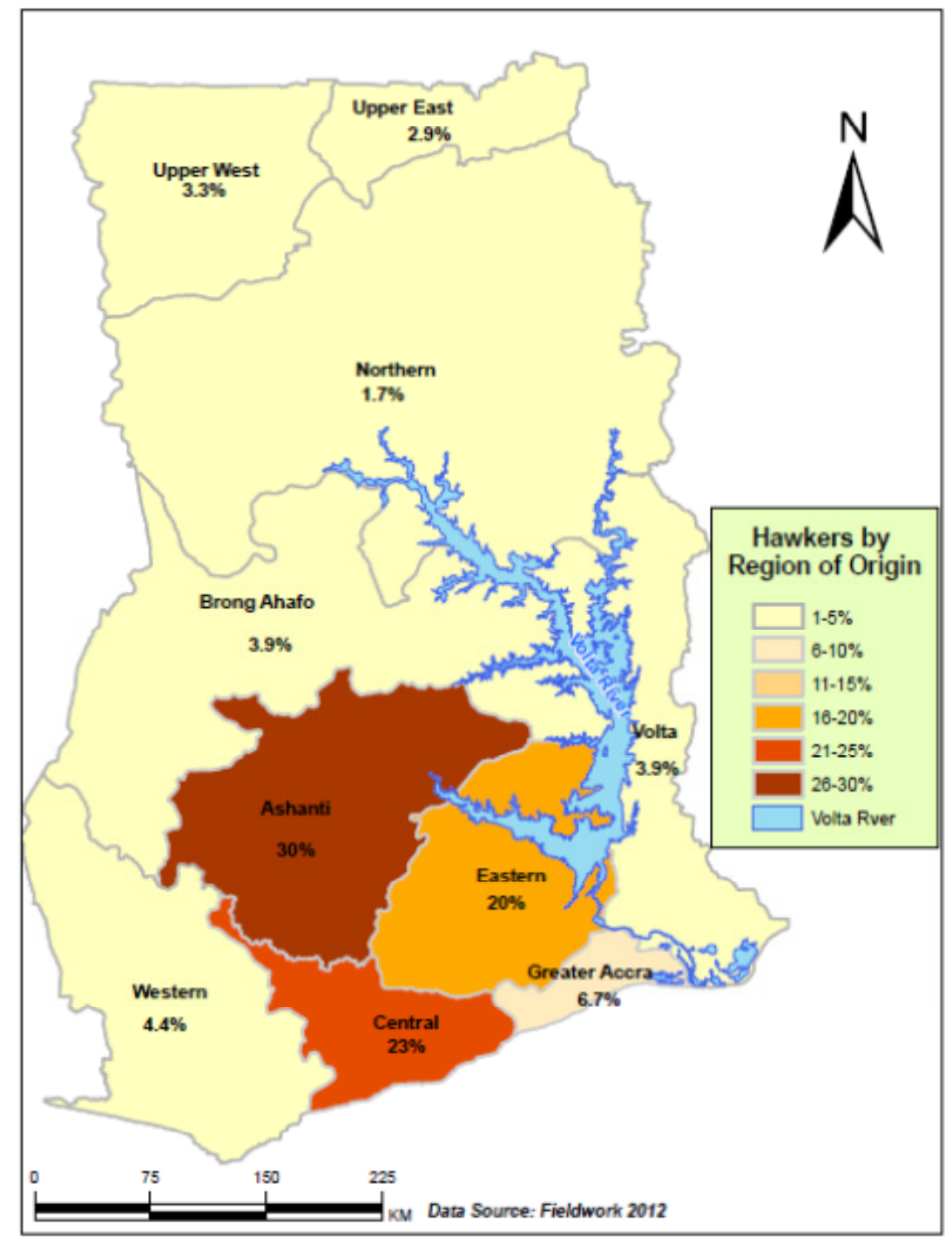

Figure 3. Number and percentage of hawkers and their region of origin

The research also considered the destination (hawking location) of choice within AMA by hawkers compared to the region of emigration. Table 1 reveals that Busy Internet area at the Kwame Nkrumah Circle as well as the Lapaz Traffic Light are more favorable hawking locations for immigrants from the Ashanti region. Meanwhile migrants from the Central Region of Ghana were observed to have higher preference for Lapaz Traffic Light and Mallam Junction locations. These two locations are on the main roads connecting Accra and the Central region. It is therefore convenient in terms of proximity and accessibility. Mallam, Airport, Lapaz Traffic Light and the Busy Internet area of the Nkrumah Circle received the highest number of migrants from the Eastern Region. The seven remaining regions recorded marginal populations between $0-4$ people per location. From the above discussion it is possible that hawkers from particular regions of the country tend to migrate to select locations for hawking. As the data becomes better resolved this could lead to the emergence hawker population differentials between locations across the urban landscape. 
Table 1. Region of origin and destination of hawkers

\begin{tabular}{|c|c|c|c|c|c|c|c|c|c|c|}
\hline $\begin{array}{l}\text { Hawking } \\
\text { locations }\end{array}$ & Ashanti & $\begin{array}{l}\text { Brong } \\
\text { Ahafo }\end{array}$ & $\begin{array}{c}\text { Upper } \\
\text { East }\end{array}$ & $\begin{array}{c}\text { Upper } \\
\text { West }\end{array}$ & Northern & Central & Eastern & $\begin{array}{c}\text { Gt } \\
\text { Accra }\end{array}$ & Western & Volta \\
\hline $\begin{array}{l}\text { Osu food } \\
\text { court }\end{array}$ & 6 & 0 & 0 & 1 & 0 & 5 & 2 & 4 & 1 & 1 \\
\hline busy internet & 10 & 1 & 0 & 0 & 0 & 1 & 5 & 3 & 0 & 0 \\
\hline $\begin{array}{c}\text { Graphic } \\
\text { Road }\end{array}$ & 6 & 1 & 1 & 2 & 1 & 5 & 1 & 0 & 0 & 3 \\
\hline $\begin{array}{c}\text { Achimota } \\
\text { New Station }\end{array}$ & 7 & 0 & 0 & 1 & 0 & 5 & 1 & 3 & 2 & 1 \\
\hline $\begin{array}{c}37 \\
\text { Roundabout }\end{array}$ & 3 & 2 & 0 & 0 & 0 & 3 & 8 & 2 & 2 & 0 \\
\hline Ind Ave. & 4 & 1 & 2 & 2 & 1 & 7 & 1 & 0 & 2 & 0 \\
\hline $\begin{array}{l}\text { Mallam } \\
\text { junction }\end{array}$ & 4 & 0 & 0 & 0 & 0 & 10 & 6 & 0 & 0 & 0 \\
\hline $\begin{array}{l}\text { Airport } \\
\text { junction }\end{array}$ & 6 & 0 & 2 & 0 & 1 & 0 & 10 & 0 & 0 & 1 \\
\hline $\begin{array}{c}\text { Abeka } \\
\text { junction }\end{array}$ & 8 & 2 & 0 & 0 & 0 & 6 & 2 & 0 & 1 & 1 \\
\hline & $54(30)$ & $7(3.9 \%)$ & $5(2.8 \%)$ & $6(3.3 \%)$ & $3(1.7 \%)$ & $42(23.3 \%)$ & $36(20 \%)$ & $12(6.7)$ & $8(4.4 \%)$ & 7(3.9) \\
\hline
\end{tabular}

\subsection{Factors Influencing the Choice of Hawking Location}

In assessing the primary factors hawkers consider in deciding on their initial and subsequent locations for hawking, a question was asked as to what factor (s) they consider in selecting their initial location for hawking and permanent (regulator hawking location). The responses from the hawkers are presented in Table 2. From Table 2, sales income is the most important factor hawkers consider when deciding where to hawk permanently or regularly. Among the 180 hawkers sampled in this study, 107 hawkers (59.4\%) chose their location based on where they are likely to make more income (most profitable). However, the 'most profitable' location is normally found by a combination of trial and error, and shared word of mouth amongst the hawkers. On the other hand, $20.6 \%$ of the respondents chose their location because they have some friends hawking in that location.

Table 2. Reasons for the choice of hawking spot by hawkers

\begin{tabular}{|c|c|c|c|c|c|c|c|c|c|c|}
\hline \multirow[t]{2}{*}{ Reasons } & \multicolumn{9}{|c|}{ Hawking Locations } & \multirow[t]{2}{*}{ Total } \\
\hline & Osu & $\begin{array}{c}\text { Nkrumah } \\
\text { Circle }\end{array}$ & $\begin{array}{c}\text { Independence } \\
\text { Avenue }\end{array}$ & $\begin{array}{l}\text { Lapaz } \\
\text { TL }\end{array}$ & Mallam & Airport & $\begin{array}{c}\text { Graphic } \\
\text { Road }\end{array}$ & Achimota & 37 & \\
\hline Profitable & 18 & 14 & 17 & 11 & 16 & 12 & 8 & 5 & 6 & $107(-59.40 \%)$ \\
\hline $\begin{array}{l}\text { To see } \\
\text { relatives }\end{array}$ & - & - & - & - & - & & - & 6 & 3 & $9(-5 \%)$ \\
\hline $\begin{array}{l}\text { To be with } \\
\text { friends }\end{array}$ & - & 6 & 3 & 4 & 4 & 2 & 9 & 5 & 4 & $37(-20.60 \%)$ \\
\hline $\begin{array}{l}\text { Less } \\
\text { harassment }\end{array}$ & 2 & - & - & - & - & 2 & 3 & - & - & $7(-3.90 \%)$ \\
\hline $\begin{array}{l}\text { No } \\
\text { alternative }\end{array}$ & - & - & - & 5 & - & 4 & - & 4 & 7 & $20(-11.10 \%)$ \\
\hline Total & 20 & 20 & 20 & 20 & 20 & 20 & 20 & 20 & 20 & $180(-100 \%)$ \\
\hline
\end{tabular}

For locations chosen based on presence of friends and relatives, hawking location affords them the opportunity to do business while enjoying the company of friends. This social capital rapturization underscores the conceptualization of livelihood, where social capital is identified as a key resource to ensuring a sustainable livelihood (Skinner, 2008; Simon, 1998). This social capital or network may serve to supply key sources of information throughout the day and act as a screen and early-warning system from the approach of City Guards. 
Among the 180 total respondents, 7 hawkers, who hawk around Osu Food Court, Airport Traffic light and Graphic Road Traffic Light think location of less harassment from AMA Task force is important. They revealed that since they had up to that time received no harassment, that location becomes the safest location to hawk even with a moderate sales turnover. Five percent of the sample mainly in the 37 Military Hospital Roundabout Traffic Light and Achimota Traffic light stated they chose their places of hawking on account of seeing relatives and people from their hometown on buses heading to their villages by which they might be able to send remittance back home. This typically means their hawking locations are on the major roads leading to their hometown. Also respondents at Lapaz Traffic Light, Airport, Achimota and the 37 military hospital road representing $11 \%$ of the total respondents also thought that there are no better alternative locations hence their keeping up with the current locations.

\subsection{Dynamics in Hawking Strategies}

In response to the temporal shifting of traffic congestion in the city, hawkers have also adopted coping strategies by choosing multiple locations throughout the day to keep pace with diurnal traffic regimes. The survey respondents indicated that they hawk in multiple locations in response to the morning, afternoon and evening traffic congestion regimes. For instance, before the completion of the George Walker Bush Highway, hawkers selling in the morning at the Airport junction would relocate to the Lapaz Traffic Light in the afternoon. After the highway was built, they would move to the Golden Tulip or the Flagstaff house in the afternoon. Some hawkers sold at the 37 Roundabout in the morning then relocated in the afternoon to the Ghana Water Company Limited and to the Flagstaff House in the evening which is along the same road (about $1 \mathrm{~km}$ apart) to take advantage of the traffic. Other hawkers also disclosed that their movement from their original place of hawking to other areas is in direct response to the influx of hawkers from other locations to their area which leads to a reduction of market share. At the Osu Food Court hawkers often go home to take care of their family when the traffic goes down usually in the late afternoon and return in the evening when the traffic levels peak. The dynamics in strategies employed by hawkers touches heavily on the prevailing circumstances but with the ultimate aim of maximizing profits. Similarly the forgoing discussion shows how hawkers compete with each other, while at the same time studying the traffic pattern and adjusting with the congestion regime. Hawking to some extent, becomes make-shift activity which varies with prevailing traffic congestion.

\subsection{Is Street Hawking Likely to End?}

In Ghana, the informal economy accounted for more than 50\% of total employment in 1987 (Nduma, 1990). The informal sector was defined to include people actively engaged in mostly retail trade such as operating in front of shops, stalls, kiosks and hawking (Cross, 1997). In spite of the inherent benefits of the informal sector to the economy of Ghana (Witt, 2008; Chen, 2001; Ebigbo, 2003), street hawking which forms a lion share of the informal sector is considered illegal, unauthorized and constitute an encroachment of public spaces. Its continual existence is a source of worry to city managers which creates conflict. Constant harassments, arrests, detention, violent evictions, multiple taxation and levies, as well as confiscation of wares by city's task force have become a daily experience for many hawkers (Suarez, 2013). In spite of these inhumane and depressing treatments, the phenomenon of street hawking has grown rapidly, riding at the back of pervasive poverty and widespread unemployment in the country. As part of the attempts to curb the recent escalating traffic congestion, the Accra Metropolitan Assembly passed a new by-law which bans street hawking and was approved by the assembly and the Local Government and took effect from Friday April 1, 2011. The by-law empowered city authorities to arrest anyone who engages in street hawking as well as those who patronize the wares of street hawkers. As per the new by-law, no one is allowed to sell any merchandise to a driver of a vehicle or a passenger whilst the vehicle is caught up in traffic or in motion. Similarly a person shall not also buy from a street hawker unless the street has been designated for that purpose.

As part of the effort to understand and assess the effectiveness of the ban, a head count of hawkers at the sample sites was taken a day before the ban came into force. This was compared with another headcount at the same locations one year after the ban. The information on percentage change one year after the ban is shown in table 3 . Interestingly 7 out of 9 major hawking locations have experienced reduction in the number of hawkers. Graphic Road Traffic Light shows the highest reduction, with a decrease hawker count of $68.3 \%$, followed by Lapaz Traffic light with a reduction of $63.8 \%$. Similarly Busy Internet area saw a reduction of 60.6 while 37 Military Traffic Light reduced by $41.9 \%$. Other locations that experienced reduction include Mallam Junction 36.6\%, Osu Food Court $18.8 \%$ and Achimota New Station Junction 13.8\%. On the contrary, two locations experienced astronomical growth in hawker numbers. These are Nima Junction traffic Light $154.1 \%$ and Airport Junction Traffic Light $133.3 \%$. While some have hailed the ban on hawking as success, it suffices to argue that it may be half the truth. A careful observation shows that although hawker concentration has gone down at many important 
locations; new hawking spots have sprung up all over town to areas that were not included in the study. Moreover the construction of N1 Highway has redistributed traffic congestion in the city which has in turn redistributed hawkers. N1 Highway, also known as George Walker Bush Highway serves as a major bypass linking four major exits from the city. These exits include the western exit which connects Accra to Central and Western Regions of Ghana and La Cote d'Ivoire, the Northern exit through Nsawam-Kumasi road, which links Accra to parts of Eastern Ashanti, Brong Ahafo and three other northern regions of Ghana. Similarly it links the main eastern exit through Tema Municipality and industrial area, the Volta region and Ghana's eastern neighboring countries of Togo, Benin and Nigeria; and finally serves as a bypass to Adenta Municipal area and the Akuapim Mountains area. Again, many people traveling from the Western parts of the city could easily use the N1 highway without the need for one to travel through major traffic congestion spots of the city. The net effect is the redirection of traffic congestion and subsequent redistribution of hawkers away from the key known sampled locations used in the study. For example the 37 Traffic light hawking point has redistributed to Christ the King Traffic light and Opabea Traffic light, a distance of approximately $1 \mathrm{~km}$ East and West of 37 Traffic Light respectively. Again it was also observed that Mallam Junction Traffic Light hawking point has spread to Sakaman and Odorkor traffic light which are about a kilometer and a kilometer and half respectively from the Mallam Junction Traffic Light.

Table 3. Percentage change in hawker count at the sampled locations one after the ban on street hawking

\begin{tabular}{lc}
\hline \multicolumn{1}{c}{ Location } & Percentage Change \\
\hline Osu Food Court & -18.8 \\
Busy Internet & -60.6 \\
Nima Junction & 154.1 \\
Lapaz Traffic Light & -63 \\
Mallam Junction Traffic Light & -36.6 \\
Airport Junction Traffic Light & 133.3 \\
Graphic Road Traffic Light & -68.3 \\
Achimota New Station & -13.8 \\
37 Military Hospital Traffic Light & -41.9 \\
\hline
\end{tabular}

Similarly, hawkers have not only moved to new locations, but have also changed their modus operandi as a way to cope with new traffic alignments and to respond to AMA task force harassment. In view of the strategies adopted by hawkers, one unanswered question lingering in the minds of many residents of the city is whether there is any clear solution to addressing hawking in Accra? In finding answers to this question the study sought the opinion of AMA officials. An interview was conducted with the AMA public affairs directorate concerning the institution's perception of hawking, the institutional approach to dealing with the phenomenon and the results of the approaches that have been used in dealing with street hawking over the years. In the view of the Assembly Public Affairs officials, street hawking by their by-laws is unacceptable, unlawful, illegal, and criminal, and will be halted by all legal means. The initial approach in dealing with this act was dialoguing and cautioning, however, as these have not yielded the desired results, in their own words "since they have failed to heed to the caution, force was being applied". The public affairs directorate believes that years of dialogue and caution have not stopped street hawking and that, in fact, it is on the ascendency affecting almost every available city space. For these reasons, AMA official stated that given the weak law enforcements coupled with the uncooperative attitudes of hawkers, arrests and increased law enforcements personnel on the streets would be the antidote. They agreed that the hawking will end but with much attention and focus than has been given and particularly, without political interference from government in power. In the past government in power lose election votes from street hawkers for backing city authorities in their efforts to evict street hawkers.

\section{Conclusions and Recommendations}

In conclusion, the study has profiled the geospatial pattern of hawkers on the streets of Accra by answering the question of why street hawking is still on the ascendency in spite of city authority's conviction to rid the city of hawkers. In general, street hawking has both spatial and temporal dynamics that make hawking more complex 
than a cursory observation will reveal. Hawkers hawk in relation to traffic congestion patterns, and these patterns exhibit temporal and spatial variations throughout the day which are not obvious at a glance. Peak hawking times are mainly morning and late afternoon. The study also shows that spatial patterns have changed as new roadways are constructed (e.g. opening of N1 highway which forms a major by-pass to Nsawam-Kumasi Highway, Tema Motorway, Adenta-Akwapim Mountains Highway and back route to eastern parts of Accra).

It can also be concluded that in availability of formal sector jobs, coupled with lack of employable skills, particularly skills required for public and other formal sector employment, preclude hawkers from participating in the formal sector. Moreover, hawkers are concerned about the harassment and molestations they received from Street Hawker eviction taskforce and other city authority agents; however, the need for survival and to take care of their dependents coupled with the precarious economic conditions of Ghana propel hawkers to grow resistant to eviction and adopt spatial game strategies to outwit law enforcers. City authorities on the other hand remain resolute and have vowed to rid the city of hawkers. In their view the current approach of forced eviction is the result of the failure of earlier attempts at negotiation and dialogue. They are now willing to pursue force eviction and prosecute street hawkers when caught in the act. Many analysts from other countries in developing world have adopted wait and see attitude to answering the question of whether city managers would be able to curtail hawking on the streets of Accra. It may be too early to predict the likely success, after-all the current ban of hawking has been in place for only one year. What can be said is that there are no clear signs of hawking slowing down in the city. Moreover given the political twist that politicians attach to eviction, and hawker resolution to stay, this study states that street hawking will be difficult if not impossible to stop.

From the foregoing discussions, the following recommendations are drawn. First, city authorities should decongest city centers, which would invariably reduce the extent of congestion on the streets. Since street hawking is mostly driven by traffic congestion hence any action that would free the flow of traffic in the city would make hawking unattractive and less profitable due to the likely reduction in sales. A second possible approach would be the reassessment and enforcement of the land use plan and code to the extent that the enforcement would include physical restrictions and barriers as to where one can enter, stop and exit from roads and street. This might prevent hawkers from gaining access to areas where hawking is profitable.

The long term solution to this street hawking problem requires political will and major policy shift from the powers of city authorities to those of the National government. Key policy issue would be the overhaul of the education and training system of the country to ensure that it becomes skill acquisition rather than literacy and numeracy training. There must be more avenues for low cost skill training so that people can acquire employable skills required by the job market. However, the success of this second prescription hinges also on the attractiveness of the formal employment in terms of competitive wage and other benefits. Similarly political opposition have over the years score political points by painting the ruling government under whose watch street hawking eviction is performed as inhumane. This is commonly found in Ghana during election campaigns and in election manifestoes that are presented by all political parties. Hence the implementation has been $a d$ hoc and at selected places. It therefore requires a strong political will to implement street hawking eviction however this study believes that political parties stand a better chance if they tackle the issue of street hawking by addressing the root cause such as job creation, educational reform to skill creation and elimination of school drop out before college level education.

\section{References}

Agbo, C. (2010). Street Hawking in Abuja Persists Despite AFPB's Ban. Retrieved from http://leadershipeditors.com/ns/index.php?option=com_content\&view=article

Asiedu, A. B., \& Agyei-Mensah, S. (2008). Traders on the run: Activities of street vendors in the Accra Metropolitan Area, Ghana. Norsk Geografisk Tidsskrift-Norwegian Journal of Geography, 62(3), 191-202. http://dx.doi.org/10.1080/00291950802335806

B Landau, L. (2007). Discrimination and development? Immigration, urbanisation and sustainable livelihoods in Johannesburg. Development Southern Africa, 24(1), 61-76. http://dx.doi.org/10.1080/03768350601165876

Bromley, R. D. F. (1998). Informal commerce: Expansion and exclusion in the historic center of Latin America city. International Journal of Urban and Regional Research, 22(2), 245-263. http://dx.doi.org/10.1111/1468-2427.00138

Chen, M. A. (2001). Women and informality: A global picture, the global movement. Sais Review, 21(1), 71-82. http://dx.doi.org/10.1353/sais.2001.0007

Cross, J. C. (1997). Entrepreneurship and exploitation: measuring independence and dependence in the informal 
economy. International Journal of Sociology and Social Policy, 17(3-4), 37-63. http://dx.doi.org/10.1108/eb013300

Dickson, K. B., Benneh, G., \& Essah, R. R. (1970). A new geography of Ghana (pp. 39-40). London: Longman.

Ebigbo, P. O. (2003). Street Children: The Core of Child Abuse and Neglect in Nigeria. Children, Youth and Environments, 13(1).

GSS (Ghana Statistical Service). (2012). 2010 Enumeration and Housing Census. Ghana Statistical Service, Accra.

Gyamfi, R. (2000). Street trading in Accra. Daily Graphic 28 March 2000, 7. Accra, Graphic Corporation.

Hart, K. (1973). Informal income opportunities and urban employment in Ghana. The journal of modern African studies, 11(01), 61-89. http://dx.doi.org/10.1017/S0022278X00008089

Hays-Mitchell, M. (1994). Street vending in Peruvian cities: the spatio-temporal behavior of ambulance. Professional Geographer, 46(4), 425-438. http://dx.doi.org/10.1111/j.0033-0124.1994.00425.x

ILO (International Labour Organization). (2002). ILO compendium of official statistics on employment in the informal sector. STAT Working Paper, 2002-No.1.

Iyenda, G. (2005). Street Enterprise, urban livelihood and poverty in Kinshasa. Environment and Urbanisation, 17(2), 55-67. http://dx.doi.org/10.1177/095624780501700205

Jimu, I. M. (2005). Negotiated economic opportunity and power: Perspectives and perceptions of the street vending in urban Malawi. Africa Development, 30(4), 35-51.

Jordan, M. (2009). Illegal Immigration from Mexico Hits Lowest Level in Decade, Wall Street. Journal, July 23rd, 2009. p. A2.

Lund, F., Nicholson, J., \& Skinner, C. (2000). Street trading. School of Development Studies, University of Natal, Durban.

Mitullah, W. V. (2003). Street Vending in Africa Cities: Synthesis of Empirical findings from Kenya, Cote d'Ivoire, Ghana, Zimbabwe, Uganda and South Africa. Background Paper for World Development Report, 2005. Washington DC: The World Bank.

Nduna, J. N. (1990). The struggles for survival of street traders in Umtata, Transkei, 1980-89. GeoJournal, 22(3), 315-319. http://dx.doi.org/10.1007/BF00711343

Nesvag, S. I. (2000). Street trading from apartheid to post-apartheid: More birds in the cornfield. International Journal of Sociology and Social Policy, 20(3-4), 34-64. http://dx.doi.org/10.1108/01443330010789115

Nnkya, T. (2006). An Enabling Framework? Governance and Street Trading in Dar es Salaam, Tanzania. In A. Brown (Ed.), Contested Space: Street Trading, Public Space, and Livelihoods in Developing Cities. Warwickshire: Intermediate Technology Publications.

Rogerson, C. M., \& Hart, D. M. (1989). The struggle for the streets: deregulation and hawking in South Africa's major urban areas. Social Dynamics, 15(1), 29-45. http://dx.doi.org/10.1080/02533958908458459

Sarfo, E. (1997). The socioeconomic impact of globalization. Globalization and Urbanisation, 12(2), 55-67.

Simon, P. B. (1998). Informal responses to crises of urban employment: an investigation into the structure and relevance of small-scale informal retailing in Kaduna, Nigeria. Regional Studies, 32(6), 547-557. http://dx.doi.org/10.1080/00343409850119111

Skinner, C. (2008). Street Trade in Africa: A Review. Centre for Development Studies Working Paper 51, University of KwaZulu-Natal.

Skinner, C. (2010). Street Trading in Africa: Demographic Trends, Planning and Traders Organization. In V. Padayachee (Ed.), Political Economy of Africa. New York: Routledge.

Suarez, C. (2013). Bracing The Odds In The Face Of Double Tragedy: The Dilemma Of Street Trading In Ibadan Metropolis Of Nigeria. European Journal of Science and Public Policy, 11, 1-9.

Vishwanath, T. (2001). Informal economy: safety valve or growth opportunity. Paper presented at the Linking Work, Skills, and Knowledge: Learning from Survival and Growth International Conference, 10-12 September, 2001, Interlaken, Switzerland.

Witt, H. (2008). Formal and Informal Economic Linkages in the Fruit and Vegetable Sector. Study 23. In A. Kraak \& K. Press (Eds.), Human Resources Development Review 2008. Durban, South Africa. 


\section{Appendix: Interview Guide}

\section{Interview Guide for Street Vendors}

This piece is part of the study being conducted by researchers of the Department of Geography and Resource Development, University of Ghana. Your candid opinions and views are therefore welcome as it will provide an invaluable feedback on how to tackle socio-economic issues affecting national development. The confidentiality of your response is assured. We seek your consent for this interview. I agree I don't agree.

1. Age

2. Sex

3. Region of origin

4. Current place of residence of street vendor.

5. What do you sell?

6. Level of education

7. Are you the bread winner of your family?

8. How many people do you cater for?

9. How long have you been selling on the street?

10. What is your average daily profit?

11. Why the particular spot?

12. How many places do you sell?

13. Was the decongestion exercise necessary / good or unnecessary / bad?

14. How best do you think the phenomenon could have been dealt with?

15. Do the city authorities seek your thoughts on activities they carry out concerning the trade?

16. Why don't you want to move to designated market area?

17. How often do task force personnel come around?

18. What is the relationship between hawkers and task force personnel?

19. Have your ware ever been confiscated by the taskforce?

20. If no to Q 17, how do you escape the task force personnel checks?

21. If yes to $\mathrm{Q} 17$, did you get your goods back?

22. If yes to $\mathrm{Q} 19$, how did you get the confiscated goods back?

23. Are you aware of the risks associated with trade?

24. Are you aware of the laws and regulation governing the allocation of space?

25. Are there traders association or unions.

26. If yes to $\mathrm{Q} 23$, are they members?

27. If yes $\mathrm{Q} 23$, what has been their contribution in securing them the best place to sell?

28. If no to $\mathrm{Q} 23$, have they thought of the benefits of joining or forming one?

29. Aside the hawking is there any job or vocation one would want to engage in as a livelihood means?

\section{Copyrights}

Copyright for this article is retained by the author(s), with first publication rights granted to the journal.

This is an open-access article distributed under the terms and conditions of the Creative Commons Attribution license (http://creativecommons.org/licenses/by/3.0/). 